\title{
Esterases in the zebra mussel Dreissena polymorpha: activities, inhibition, and binding to organophosphates
}

\author{
Carole Dauberschmidt ${ }^{1, *}$, Daniel R. Dietrich ${ }^{2}$, Christian Schlatter \\ Institute of Toxicology, Federal Institute of Technology and University of Zürich, Schorenstrasse 16, \\ CH-8603 Schwerzenbach, Switzerland
}

\begin{abstract}
Cholinesterase activities of Dreissena polymorpha were measured colorimetrically. In homogenates of whole control mussel, activities of $125 \pm 29 \mu \mathrm{mol} \mathrm{min}-1 \mathrm{~kg}^{-1}$ were found $(n=6)$. Neither after exposure of Dreissena to organophosphates (thiometon, disulfoton, demeton- $S$ methyl) nor after addition of demeton- $S$-methyl (the activated oxygen analogue of thiometon) in vitro was the measured mussel esterase activity inhibited. Esterases of rat, mouse and human tissue showed a 90-100\% inhibition. Radiolabelling of the active serine site of esterases in muscle homogenates with ${ }^{3} \mathrm{H}$-diisopropylfluorophosphate and subsequent separation on polyacrylamide gels revealed similarities as well as differences between rat and mussel esterases. Coomassie-stained muscle proteins of Dreissena showed a different distribution pattern than those of rat. Proteins of rat as well as proteins of mussel with molecular weights between 66 and $97 \mathrm{kDa}$ showed best labelling (highest radioactivity). Proteins with molecular weights greater than $97 \mathrm{kDa}$ were not labelled. Additionally, in Dreissena but not in rat, proteins of around $45 \mathrm{kDa}$ were labelled. The results indicate that the esteratic enzymes in Dreissena were labelled but not inhibited by organophosphates.
\end{abstract}

Keywords: Dreissena polymorpha; Organophosphate; Acetylcholinesterase; Radiolabelling; Diisopropylfluorophosphate

\section{Introduction}

The freshwater mollusc Dreissena polymorpha (zebra mussel) was shown to be highly resistant towards organophosphate insecticides and their activated oxygen

\footnotetext{
*Corresponding author.

1 Present address: SOGEDEC, 14, rue Auguste Lumière, L-1950 Luxembourg, Luxembourg.

${ }^{2}$ Present address: Ecotoxicology, University of Konstanz, D-78434 Konstanz, Germany.
} 
analogues (Dauberschmidt et al., 1996). This is true, in spite of an observed accumulation of the organophosphates thiometon and disulfoton in the tissue of these molluscs. In vertebrates, organophosphates inhibit the acetylcholinesterase at the motoneural endplates, which among other effects may lead to lethal failure of respiratory muscles. Metabolism of commercial agricultural organophosphates takes place very quickly in mammals, usually to highly toxic and potent cholinesterase-inhibiting oxygen analogues followed by hydrolytic steps to inactive compounds. At high concentrations however, the parent compound itself inhibits the cholinesterases as well (Gallo and Lawryk, 1991). Accumulation of organophosphates such as observed in Dreissena as well as in some fish (Zinkl et al., 1991) indicates slow metabolism and consequently questions an activation of the parent compound to a powerful cholinesterase inhibiting intermediate.

Although there is no doubt that organophosphates exert their toxicity by inhibiting cholinesterases of homeotherm vertebrates, there seems to be less evidence when looking more specifically at several different groups of animals. Fish for example usually show acetylcholinesterase inhibition upon exposure to organophosphates, but some fish species do not (Zinkl et al., 1991; Arnold and Braunbeck, 1992). Frog acetylcholinesterases show extremely low inhibition rates and therefore high resistance towards organophosphate inhibition compared to chicken and rat (Andersen et al., 1977). Furthermore, the inhibition of acetylcholinesterase even in insects is not fully understood despite the fact that organophosphates have served worldwide as efficient insecticides for years (Fest and Schmidt, 1970).

Species differences in organophosphorus pesticide toxicity have been related to lower esterase activities, such as in ticks (Wharton and Roulston, 1970) and some bird species (Thompson et al., 1991), as well as to cholinesterase modifications which evolved in organophosphate-resistant insects (Hemingway and Georghiou, 1983).

Cholinesterases are found in all animal phylas (Walker and Thompson, 1991) including molluscs, but the knowledge about structure, function, and distribution is very scarce in the case of invertebrates. It appears as if insects and molluscs present a higher diversity of cholinesterases than what is known for mammals (Edwards and Fisher, 1991; Habig and Di Giulio, 1991). From the variety of cholinesterase forms found in the animal kingdom and their inherent characteristics, it can be postulated that cholinesterases from invertebrates might represent an intermediate evolutionary level between the more evolved forms of vertebrates and a possible ancestral esterase (Johnson, 1990). Furthermore, it has been shown that the separation between acetyl- and butyrylcholinesterase genes occurred long after the divergence of vertebrates and insects (Chatonnet and Jbilo, 1990).

Due to the above-described resistance of zebra mussels exposed to organophosphates, the interaction of organophosphorus insecticides with zebra mussel acetylcholinesterase was of interest. The aim of this study was to elucidate some characteristics of cholinesterases in Dreissena and determine whether these findings would allow a better understanding of the effects of organophosphates on the enzyme systems of these molluscs.

Measurements of cholinesterase activity of Dreissena in the presence of inhibitors 
were carried out. Additionally, staining of active serine sites of esterases in muscle homogenates with radiolabelled inhibitory organophosphate and subsequent protein separation on polyacrylamide gels was performed.

\section{Materials and methods}

\subsection{Measurement of cholinesterase activity}

\subsubsection{Collection of Dreissena and pretreatment}

Mussels were collected from Lake Zurich. Exposure to the organophosphates thiometon, disulfoton and demeton- $S$-methyl followed as described in Dauberschmidt et al. (1996). Briefly, mussels (valve length $1.6-2.3 \mathrm{~cm}$ ) were placed into covered glass aquaria containing $7.5 \mathrm{~L}$ of dechlorinated tap water $\left(18^{\circ} \mathrm{C}\right)$ which was continuously recirculated. The experiments were carried out by adding the same amounts of the respective organophosphates to the aquaria once every $24 \mathrm{~h}$ for a total of four times (Table 1). Dead mussels (lacking shell closing reflex) were removed daily, and mussels surviving the $96 \mathrm{~h}$ experimental period were stored at $-20^{\circ} \mathrm{C}$ until further processing.

\subsubsection{Cholinesterase assay}

Determination the cholinesterase activities was based mainly on the method of Ellman et al. (1961) with minor modifications as described in Hill (1988). The reagents were purchased from Boehringer diagnostics, Mannheim FRG as a kit for measuring serum cholinesterase activity. Esterase activity of human plasma can be measured directly without prior preparation. In order to measure activities of tissues, homogenates were prepared as described in Hill (1988). Mussels were thawed, shucked and the excess water was drained off. Weighed tissue (single whole mussels, pooled dissected posterior adductor muscle of Dreissena, leg muscle tissue from rat and mouse) was homogenised in $0.05 \mathrm{M}$ Tris buffer ( $\mathrm{pH} \mathrm{8}$ ) at a ratio of $1 \mathrm{~g} \mathrm{ml}^{-1}$ with a power driven homogeniser.

For assaying cholinesterase activity, acetylthiocholine iodide was added as substrate to mixed tissue homogenate with the buffer/chromagen reagent dithiobisnitrobenzoic acid. Reactions were conducted in $2 \mathrm{ml}$ disposable polystyrene photocells with a $1 \mathrm{~cm}$ light path. After stirring, the solution was allowed to stabilise for 4-6 min. The sample was placed in a Perkin Elmer 554 spectrophotometer set at a wavelength of $405 \mathrm{~nm}$ and change of absorbance was measured for 2-3 min at room temperature. The average change of absorbance per minute was calculated using the following equation (Fairbrother et al., 1991):

$$
\frac{\Delta \mathrm{conc}}{\min }=\frac{\Delta \mathrm{abs} \times \mu \mathrm{mol} \times \mathrm{Rxn}}{\min \times E \times \mathrm{Smpl} \times \mathrm{ml}}
$$

where $\Delta$ conc, abs is the change in concentration, absorbance, respectively, Rxn, 
Smpl is the reaction mixture volume, sample volume, respectively, $E$ is the extinction coefficient $\left(13.6 \times 10^{3} \mathrm{M}^{-1} \mathrm{~cm}^{-1}\right)$.

Cholinesterase activity is usually reported in $\mu \mathrm{mol}$ of acetylcholine iodide hydrolysed per min per $\mathrm{g}$ (or $\mathrm{kg}$ ) of tissue (wet weight, ww) at room temperature ( $1 \mathrm{U}=1 \mathrm{IU}=1$ International Unit $=\mu \mathrm{mol} \mathrm{g}^{-1} \mathrm{~min}, 10^{3} \mathrm{U} \mathrm{kg}^{-1}$, respectively).

\subsubsection{Inhibition}

Cholinesterase activity inhibition was measured upon addition of $0.1 \mathrm{mg} \mathrm{ml}^{-1}$ demeton- $S$-methyl (the activated thiometon analogue) together to human plasma or the respective tissue homogenates into the cuvette. Demeton- $S$-methyl was obtained from Dr. Ehrenstorfer GmbH, Augsburg, FRG (purity 95.2\%). It was dissolved at $1 \mathrm{mg} \mathrm{ml}^{-1}$ in $n$-hexane.

\subsection{Gels and labelling}

\subsubsection{Sample preparation, protein assay}

The homogenates were prepared as described for the cholinesterase assay. The protein contents of the homogenates was determined by the method of Bradford (1976), using bovine serum albumin as standard. Measurements were carried out automatically on a Cobas Fara chemistry analyser (Roche, Switzerland).

\subsubsection{Active site labelling of esterases}

- Tritiated diisopropylfluorophosphate $\left({ }^{3} \mathrm{H}-\mathrm{DFP}\right)$, an inhibitor of serine esterases, was used to specifically radiolabel cholinesterases present in homogenates for detection. DFP was obtained from Dupont, NEN Products $\left(1 \mathrm{mCi} \mathrm{ml}^{-1}\right.$ in propylene glycol). The reference esterases acetylcholinesterase (AChE, EC 3.1.1.7, specific enzyme activity $2 \mathrm{U} \mathrm{mg}^{-1}$ ), butyrylcholinesterase (BChE, EC 3.1.1.8, $5 \mathrm{U}$ $\mathrm{mg}^{-1}$ ) and carboxylesterase (CbE, EC 3.1.1.1, $130 \mathrm{U} \mathrm{mg}^{-1}$ ) were purchased from Boehringer Mannheim. One enzyme activity unit of the reference esterases and $300-400 \mu \mathrm{g}$ homogenate proteins were incubated for $1 \mathrm{~h}$ at room temperature with $0.01 \mu \mathrm{Ci}{ }^{3} \mathrm{H}$-DFP in a final volume of $200 \mu \mathrm{l}$. Thereafter, $10 \mu \mathrm{l}$ cold DFP $\left(10^{-4} \mathrm{M}\right.$, Fluka) and $0.8 \mathrm{ml}$ of $30 \%$ ice-cold trichloroacetic acid (TCA, Sigma) was added. After centrifugation $\left(10000 \mathrm{~g}, 5 \mathrm{~min}, 4^{\circ} \mathrm{C}\right.$ ), precipitates were washed sequentially in $1 \mathrm{ml}$ of $10 \%$ and $1 \%$ TCA by centrifugation. Precipitates were finally dissolved in urea sample buffer as described below.

\subsubsection{Protein separation ( $S D S-P A G E)$}

Homogenates were mixed at an approximate ratio of $1: 3(\mathrm{v} / \mathrm{v})$ with lysis buffer $(150 \mathrm{mM}$ Tris- $\mathrm{HCl} \mathrm{pH} 6.8,200 \mathrm{mM}$ dithiothreitol, $6 \%$ w/v SDS, $0.3 \% \mathrm{w} / \mathrm{v}$ bromphenolblue, $30 \% \mathrm{v} / \mathrm{v}$ glycerol), and boiled for $5 \mathrm{~min}$. SDS-PAGE was performed according to Laemmli (1970), using a 4\% stacking gel and a 6 or $7.5 \%$ separating gel. High and low molecular weight (mol. wt.) marker were purchased from Sigma. Electrophoresis was run in BioRad mini-vertical gel cells. The gels were stained $30 \mathrm{~min}$ in methanol : acetic acid : water $(4: 1: 5 \mathrm{v} / \mathrm{v} / \mathrm{v})$ containing 

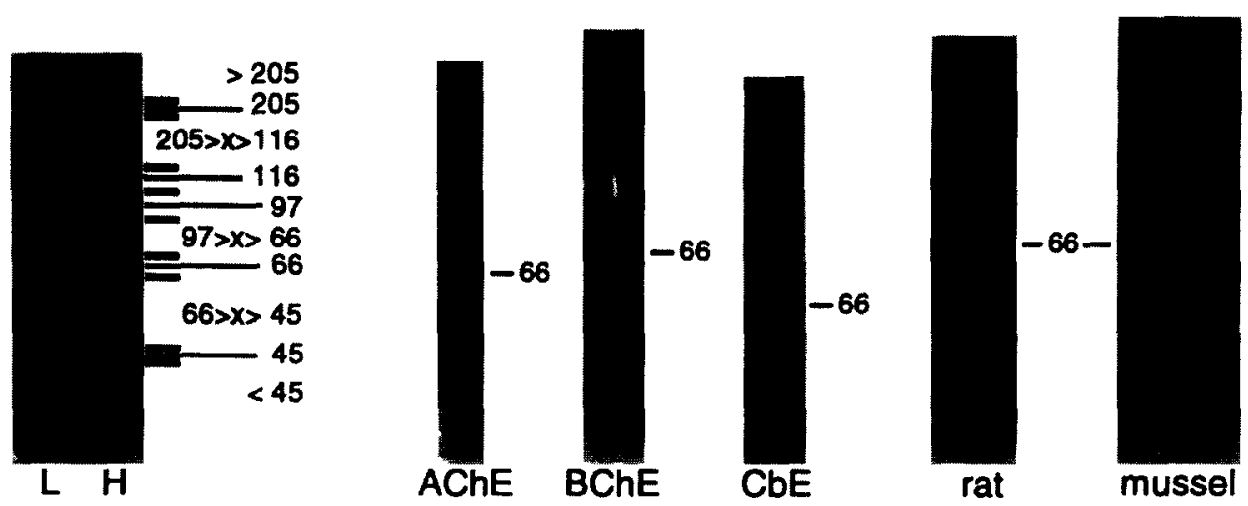

Fig. 1. Coomassie-stained gels of rat and mussel muscle protein and the reference esterases $\mathrm{AChE}$, $\mathrm{BChE}, \mathrm{CbE}$. The bold lines beside the gel of the low $(\mathrm{L})$ and high $(\mathrm{H}) \mathrm{mol}$. wt. marker indicate where the lanes were cut in order to obtain 10 different mol. wt. $(\mathrm{kDa})$ bands for radioactivity counting.

$0.25 \%$ coomassie blue, and the background subsequently destained over $12 \mathrm{~h}$ by several changes of methanol : acetic acid : water $(5: 7: 88 \mathrm{v} / \mathrm{v} / \mathrm{v})$.

\subsubsection{Detection of DFP-binding proteins}

After destaining, the gels containing radiolabelled proteins were dried on blotting-paper under vacuum at $80^{\circ} \mathrm{C}$ for $2 \mathrm{~h}$. The single sample lanes of the dried gels were cut into several mol. wt. bands (Fig. 1). Apparent mol. wt. was determined from electrophoretic mobilities compared with the markers. The bands were then combusted completely with a Canberra Packard oxidiser 306. The condensed tritium water was mixed in liquid scintillation cocktail and the activity was counted with a Beckman LS 6000LL Series Liquid Scintillation System.

Table 1

Cholinesterase (ChE) activities of homogenates of Dreissena polymorpha exposed to thiophosphates and demeton-S-methyl, the active oxygen analogue of thiometon

\begin{tabular}{lllcc}
\hline Exposure & & & $\begin{array}{l}\mathrm{ChE} \text { activity }(\mu \mathrm{mol} \\
\left.\mathrm{min}^{-1} \mathbf{k g}^{-1} \mathrm{ww}\right)\end{array}$ \\
\hline duration & chemical & amount added daily $\left(\mathrm{mg} \mathrm{L}^{-1}\right)$ & \\
\hline control & & & $125 \pm 29$ & 6 \\
$96 \mathrm{~h}$ & thiometon & 6 & $121 \pm 69$ & 3 \\
$96 \mathrm{~h}$ & disulfoton & 10 & $91 \pm 40$ & 3 \\
$96 \mathrm{~h}$ & demeton- $S$-methyl & 6 & $113 \pm 42$ & 3 \\
$>72 \mathrm{~h}^{\text {a }}$ & thiometon & 12 or 50 & $110 \pm 37$ & 3 \\
\hline
\end{tabular}

\footnotetext{
${ }^{a}$ Mussels died last day of exposure.
} 
Table 2

Cholinesterase activities of respective tissues of human, rat, mouse, and Dreissena and inhibition in presence of $0.1 \mathrm{mg} \mathrm{ml}^{-1}$ demeton-S-methyl $(n=2)$

\begin{tabular}{lcc}
\hline Tissue & ChE activity $\left(\mu \mathrm{mol}^{-1} \operatorname{min~kg}^{-1}\right.$ ww) & Inhibition (\%) \\
\hline human plasma & $2507 \pm 62$ & 100 \\
rat muscle & $610 \pm 41$ & 89 \\
mouse muscle & $562 \pm 2$ & 100 \\
mussel muscle & $106 \pm 4$ & 0 \\
\hline
\end{tabular}

\section{Results}

\subsection{Enzyme activities and inhibition}

The mussel homogenates of differently exposed mussels showed no significant inhibition of their cholinesterases, irrespective of the organophosphate they were exposed to and whether the exposure caused death (Table 1). Furthermore, the acetylcholinesterase activity remained unchanged even in Dreissena that presumably had died of organophosphate exposure after $72 \mathrm{~h}$.

Normal activity and activity after application of demeton-S-methyl were measured in muscle homogenates of Dreissena, rat and mouse (Table 2). Cholinesterase activities of vertebrate muscle were around six times higher than those of the mussel muscle. Addition of $0.1 \mathrm{mg} \mathrm{m}^{-1}$ demeton- $S$-methyl caused an almost total inhibition of the vertebrate plasma and muscle cholinesterase activity. No inhibition of the mussel cholinesterase of whole animal or muscle homogenate could be observed.

\subsection{Protein separation and enzyme labelling}

In Fig. 1, the coomassie-stained bands of subunits of $\mathrm{AChE}, \mathrm{BChE}$ and $\mathrm{CbE}$ can

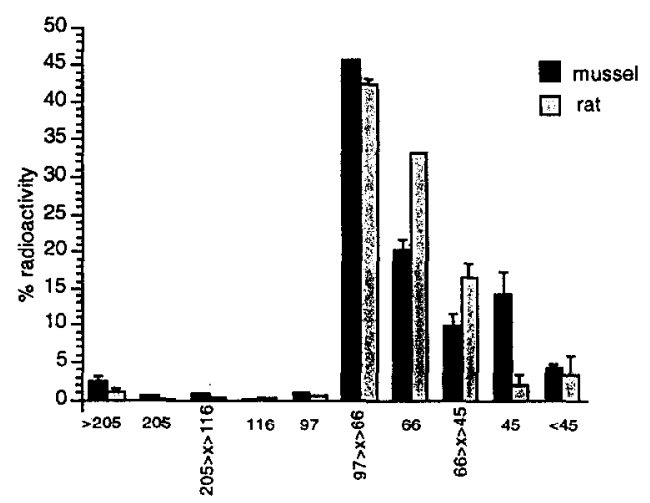

Fig. 2. Molecular weight estimation ( $x$ in $\mathrm{kDa}$ ) for DFP-binding proteins in rat and musscl musclc homogenate. Average $(n=2)$ relative radioactivity of bands combusted (summed radioactivity of whole lane $\Sigma=100 \%$ ). 
be seen. Muscle protein of Dreissena show a different pattern of distribution than those of rat. Whereas some bands in the rat homogenate could account for esterases, in the mussel lane no stained bands are detectable at the mol. wt. height of the reference esterases. Comparing mol. wts. of proteins is only a very rough approach however, which must be rendered more sensitive with the results of specific labelling of esterases with DFP.

On SDS-PAGE, peaks of radioactivity (best labelling) of $\mathrm{CbE}$ and $\mathrm{AChE}$ were at mol. wt. $66>x>45$. For BChE they were at mol. wt. $97>x>66$. The peaks correspond to the mol. wts. of these enzymes, being $58-61 \mathrm{kDa}$ in the case of $\mathrm{CbE}, 62$ for the $\mathrm{AChE}$ subunit, and between 86 and $92 \mathrm{kDa}$ for the subunits of BChE. Radioactivity in rat muscle was highest at mol. wt. $97>x>66$. No activity was found at mol. wt. $>97 \mathrm{kDa}$, and constantly decreasing activities at mol. wts. $<66 \mathrm{kDa}$ (Fig. 2). The peak of activity of mussel protein was also at mol. wt. $97>x>66$. The activity in subsequent bands decreased faster than in rat and an additional peak was apparent around mol. wt. $45 \mathrm{kDa}$.

Due to the relatively high amounts of proteins used $(300-400 \mu \mathrm{g})$, it was not always possible to resolve the whole TCA precipitated pellet in the urea sample buffer and load it onto the gel. A relative quantification was nevertheless accurate as completely dissolved and loaded proteins showed the same activity pattern as when not the whole pellet was dissolved. Absolute quantification of the binding sites was only possible between samples with similar remaining activity in the pellet (determined by combustion as well) or completely dissolved and loaded proteins. A first estimation showed that Dreissena has around one-half to one-third fewer binding sites per mg protein incubated than rat.

\section{Discussion}

\subsection{Enzyme activity}

Positive results obtained with a colorimetric method require careful interpretation. Other components able to induce the colour reaction have to be considered. As no more activity could be detected when the proteins were denatured (boiled) prior to measurement in the experiment reported here, it is very probable that the positive reaction was enzyme induced. It can therefore be concluded that also in mussels an enzyme able to hydrolyse cholinesters caused the positive reaction.

The activities of the whole mussel tissue are comparable to earlier measurements in other bivalves (Salanki et al., 1966). Activities of specific tissues show a haemolymph esterase activity in Mytilus of 94 U (Von Wachtendonk and Neef, 1975). In the central nervous system of the bivalve Anodonta an activity of $230 \mathrm{U} \mathrm{kg}^{-1}$ was measured, which is approximately twice the activity measured in the whole mussel tissue of Dreissena.

The fact that the cholinesterase activities in tissue of Dreissena was around six times below the activities measured in rat and mouse tissue (Table 2) corresponds to generally low enzyme activities in molluscs (Payne et al., 1987). Comparisons be- 
tween unrelated species however need careful interpretation. Measuring enzyme activities in species for which the test methods were not originally designed usually does not take into account species specificities such as optimal enzyme reaction temperature.

Almost all the research that has been carried out so far on cholinesterase inhibiting capabilities of organophosphate, has involved vertebrate species. In invertebrate species, inhibition of the acetylcholinesterase by pesticides and other cholinergic compounds were reported for insects, mites, molluscs, earthworms and nematodes (Edwards and Fisher, 1991), in Planaria (Villar et al., 1994) and in snails (Varanka, 1968; Singh and Agarwal, 1983). A freshwater mussel die-off was attributed to poisoning by the organophosphate orthene and the carbamate lannate as the cholinesterase activities of the adductor muscles were depressed up to $73 \%$ (Fleming et al., 1995). However, the findings from this study demonstrate that the individual variation of mussel cholinesterase activity between single specimens of Dreissena was larger than the influence from exposition to organophosphates or type of organophosphate (Table 1). This means that a potential inhibition of the mussel cholinesterase by organophosphates is zero or low enough to be hidden by factors such as individual variation of enzyme activities and, if exposed, their unspecific reactions towards the chemicals tested. As an esterase inhibition by organophosphates could not be detected in the freshwater mollusc Dreissena even after adding high amounts of active thiometon metabolite to the measuring system in vitro (Table 2), it may be concluded that esterases of Dreissena are not inhibited by organophosphates in vivo either.

Low inhibition rates of cholinesterases can be caused by differences in phosphorylation and dephosphorylation rates of the active serine of the esterase molecule, and differences in the affinity of the inhibitors to the active site (Andersen et al., 1977). A lower affinity and/or higher dissociation of the mussel esterase-substrate bond, the (de)phosphorylation rate, could therefore to some extent explain lower inhibition and thus higher resistance towards organophosphates (see Introduction), but not the observed complete lack of inhibition in mussel homogenates (Table 2).

On the non-enzymatic level, other additional features may further explain resistance. As filter-feeding organisms, the respiratory system in Dreissena is, due to its biology of ciliar movements, almost independent from muscles (Czihak et al., 1981; Morton, 1969). The existence of cholinergic transmission in the peripheral nervous system in molluses has so far not been demonstrated. Acetylcholine (Gerschenfeld, 1973; Heyer et al., 1973; Mercer and McGregor, 1982) or cholinesterase activity may therefore not be essential (Lloyd, 1991; Rosza, 1984).

\subsection{Labelling}

The comparison of the coomassie-stained pattern with the occurrence of labelled proteins shows the selective DFP-binding to specific proteins (Figs. 1 and 2). It must however be considered that beside cholinesters (Blackburn and Selkirk, 1992), other hydrolases such as proteases contain active serine sites and are labelled with DFP as well (Daja et al., 1993). Figs. 1 and 2 further demonstrate that proteins not 
visible with coomassie staining are revealed with radioactive labelling. In earlier studies, the DFP-binding of proteins were made visible by autoradiography (Blackburn and Selkirk, 1992; Benyon et al., 1993; Daja et al., 1993). Burning the gel bands and counting the activity of the obtained tritium water in scintillation liquid has, partly because of the weak energy radiation of tritium, several advantages compared to radiographic methods. First of all, activities down to a few dpm per band of around $20 \mathrm{~mm}^{2}$ can be counted. Secondly, the long exposure times necessary for autoradiography can be avoided. Finally, the absolute decays obtained allow for a much better quantification than black spots on films. The disadvantage of this method was that one loses some of the information on the definition of the bands.

Supposing that all the DFP-labelled proteins were esterases, the estimated two to three times fewer active binding sites to DFP per mg protein of Dreissena compared to rat (see Results) indicate that only part of the six times lower activity can be explained by lower enzyme concentration. The other part may be explained for example by slower hydrolysis of the enzyme acetate bond (dissociation).

The DFP-labelled proteins of Dreissena showed in comparison to rat an additional activity peak at a position around $45 \mathrm{kDa}$ (Fig. 2). This compares well with the findings of Blackburn and Selkirk (1992), who observed that separation of nematode acetylcholinesterase with SDS-PAGE revealed two isoforms. Blackburn and Selkirk suggested that the catalytic subunit of $39 \mathrm{kDa}$ was a processed derivate from the $74 \mathrm{kDa}$ isoform. Processing of a higher mol. wt. acetylcholinesterase into smaller subunits has been observed also in other invertebrates such as trematodes, Drosophila, house fly (Blackburn and Selkirk, 1992) and in the bivalve mollusc Mytilus with subunits of about $39 \mathrm{kDa}$ as well (Von Wachtendonk and Neef, 1975).

\section{Conclusions}

The esteratic enzymes in Dreissena were not inhibited by the active organophosphate demeton- $S$-methyl. This corroborates the earlier observed resistance of zebra mussels towards exposure to organophosphates (Dauberschmidt et al., 1996). Consequently, the classical model for toxic action of organophosphates by acetylcholinesterase inhibition is not applicable to zebra mussels. An independent evolution of mollusc esterases and vertebrate cholinesterase going back to the early phylogenetic divergence (Johnson, 1990) may have led to sterical differences and thus to a sterical protection of the active sites of the mussel esterases (Andersen et al., 1977). Why and which mussel proteins were nevertheless radiolabelled by organophosphates remains to be understood.

\section{Acknowledgements}

This study was supported by a grant from the Swiss Federal Institute of Technology of Zurich (Grant No. 0-20-544-91). Thanks are due to Dr. Ch. Senstag for helpful suggestions and critical reading of the manuscript. 


\section{References}

Andersen, R.A., Aaraas, I., Gaare, G. and Fonnum, F., 1977. Inhibition of acetylcholinesterase from different species by organophosphorus compounds, carbamates and methylsulphonylfluoride. Gen. Pharmacol., 8: 331-334.

Arnold, H. and Braunbeck, T., 1992. Disulfoton as a major toxicant in the river Rhine chemical spill at Basle in 1986: acute and chronic studies with eel and rainbow trout. In EIFAC/XVII/Symp. E9.

Benyon, R.C., Enciso, J.A. and Befus, A.D., 1993. Analysis of human skin mast cell proteins by twodimensional gel electrophoresis. J. Immunol., 151: 2699-2706.

Blackburn, C.C. and Selkirk, M.E., 1992. Characterisation of the secretory acetylcholinesterases from adult Nippostrongylus brasiliensis. Mol. Biochem. Parasitol., 53: 79-88.

Bradford, M.M., 1976. A rapid and sensitive method for the quantitation of microgram quantities of protein utilizing the principle of protein dye binding. Anal. Biochem., 72: 248-254.

Chatonnet, A. and Jbilo, O., 1990. Rabbit butyrylcholinesterase gene: an evolutionary perspective. In: J. Massoulié, F. Bacou, E. Barnard and A. Chantonnet, B.P. Doctor and D.M. Quinn (Editors). 3rd Intcrnational Meeting on Cholinestcrases. American Chemical Society, La Grande Motte, France, pp. $157-161$.

Czihak, G., Langer, H. and Ziegler, H., 1981. Biologie. Ein Lehrbuch. Springer, Berlin.

Daja, M.M., Hiyama, J., Scott, K.G. and Renwick, A.G.C., 1993. The detection and isolation of protease activity associated with purified preparations of human chorionic gonadotropin. Endocrinology, 132: 1766-1773.

Dauberschmidt, C., Dietrich, D.R. and Schlatter, C., 1996. Toxicity of organophosphorus insecticides in the zebra mussel Dreissena polymorpha P. Arch. Environ. Contam. Toxicol., 30: 373-378.

Edwards, C.A. and Fisher, S.W., 1991. The use of cholinesterase measurements in assessing the impacts of pesticides on terrestrial and aquatic invertebrates. In: P. Mineau (Editor). Cholinesterase-inhibiting Insecticides. Elsevier, Amsterdam, pp. 255-275.

Ellman, G.L., Courtney, K.D., Anders, Jr., V. and Featherstone, R.M., 1961. A new and rapid colorimetric determination of acetylcholinesterase activity. Biochem. Pharmacol., 7: 88-95.

Fairbrother, A., Marden, B.T., Bennett, J.K. and Hooperds, M.G., 1991. Methods used in determination of cholinesterase activity. In: P. Mineau (Editor). Cholinesterase-inhibiting Insecticides. Elsevier, Amsterdam, pp. 35-69.

Fest, C. and Schmidt, K.J., 1970. Insektizide Phosphorsäureester. In: R. Wegler (Editor). Chemie der Pflanzenschutz- und Schädlingsbekämpfungsmittel. Springer, Berlin, pp. 246-453.

Fleming, W.J., Augspurger, T.P. and Alderman, J.A., 1995. Freshwater mussel die-off attributed to anticholinesterase poisoning. Environ. Toxicol. Chem., 14: 877-879.

Gallo, M.A. and Lawryk, N.J., 1991. Organic phosphorus pesticides. In: W.J. Hayes and E.R. Laws (Editors). Handbook of Pesticide Toxicology. Academic Press, San Diego, pp. 917-1090.

Gerschenfeld, H.M., 1973. Chemical transmissions in invertebrate nervous systems and neuromuscular junctions. Physiol. Rev., 53: 1-119.

Habig, C. and Di Giulio, R.T., 1991. Biochemical characteristics of cholinesterases in aquatic organisms. In: P. Mineau (Editor). Cholinesterase-inhibiting Insecticides. Elsevier, Amsterdam, pp. 19-33.

Hemingway, J. and Georghiou, G.P., 1983. Studies on the acetylcholinesterase of Anopheles albimanus resistant and susceptible to organophosphate and carbamate insecticides. Biochem. Physiol., 19: 167171.

Heyer, C.B., Kater, S.B. and Karlsson, U.L., 1973. Neuromuscular systems in molluscs. Am. Lool., 13: $247-270$.

Hill, E.F., 1988. Brain cholinesterase activity of apparently normal wild birds. J. Wildlife Dis., $24: 51-61$. Johnson, C.D., 1990. Nematode acetylcholinesterases: diversity and functions. In: J. Massoulié, F. Bacou, E. Barnard, A. Chantonnet, B.P. Doctor and D.M. Quinn (Editors). 3rd International Meeting on Cholinesterases. American Chemical Society, La Grande Motte, France, pp. 136-140.

Laemmli, U.K., 1970. Cleavage of structural proteins during the assembly of the head of bacteriophage T4. Nature, 227: 680-685. 
Lloyd, P.E., 1991. Absence of acetylcholinesterase (AChE) activity at cholinergic neuromuscular synapses in Aplysia. Soc. Neurosci. Abstr., 17: 1355.

Mercer, A.L. and McGregor D.D., 1982. Neural regulation and pharmacology of the gut of Chione stutchburyi, a bivalve mollusc. Comp. Biochem. Physiol., 73C: 243-251.

Morton, B., 1969. Studies on the biology of Dreissena polymorpha Pall. I. General introduction. Proc. Malac. Soc. London, 38: 301-321.

Payne, J.F., Fancey, L.L., Rahimtula, A.D. and Porter, E.L., 1987. Review and perspective on the use of mixed-function oxygenase enzymes in biological monitoring. Comp. Biochem. Physiol., 86C: 233-245.

Rosza, K., 1984. The pharmacology of molluscan neurons. Prog. Neurobiol., 23: 79-150.

Salanki, J., IIiripi, L. and Labos, E., 1966. Cholinesterase activity in the central nervous system of Anadonta cygnea L. Annal. Biol. Tihany, 33: 143-150.

Singh, D.K. and Agarwal, R.A., 1983. In vivo and in vitro studies on synergism with acetylcholinesterase pesticides in the snail Lymnaea acuminata. Arch. Environ. Contam. Toxicol., 12: 483-487.

Thompson, H.M., Mackness, M.I., Walker, C.H. and Hardy, A.R., 1991. Species differences in avian serum B esterases revealed by chromatofocusing and possible relationships of esterase activity to pesticide toxicity. Biochem. Pharmcol., 41: 1235-1240.

Varanka, I., 1968. Biochemical investigation of cholinesterase in the central nervous system of Lymnaea stagnalis L. (Gastropoda). Annal. Biol. Tihany, 35: 93-107.

Villar, D., Gonzalez, M., Gualda, M.J. and Schaeffer, D.J., 1994. Effects of organophosphorus insecticides on Duglesia tigrina: Cholinesterase activity and head regeneration. Bull. Environ. Contam. Toxicol., 52: 319-324.

Von Wachtendonk, D. and Neef, J., 1975. Isolation, purification and molecular properties of an acetylcholinesterase (E.C. 3.1.1.7) from the haemolymph of the sea mussel Mytilus edulis. Comp. Biochem. Physiol., 63C: 279-286.

Walker, C.H. and Thompson, H.M., 1991. Phylogenetic distribution of cholinesterases and related esterases. In: P. Mineau (Editor). Cholinesterase-inhibiting Insecticides. Elsevier, Amsterdan, pp. 1 17.

Wharton, R.H, and Roulston, W.H., 1970. Resistance of ticks to chemicals. Ann. Rev. Entom., 15: 381404.

Zinkl, J.G., Lockhart, W.L., Kenny, S.A. and Ward, F.J., 1991. The effects of cholinesterase inhibiting insecticides on fish. In: P. Mineau (Editor). Cholinesterase-inhibiting Insecticides. Elsevier, Amsterdam, pp. 233-254. 